\title{
Looking at Socially Integrative Cities through the Educating City: The Example of Educational Museums in Europe and China
}

\author{
Fabrizio d'Aniello, Zhuqing Xu, Elisabetta Patrizi and Stefano Polenta
}

\section{Introduction: The Educating City}

The concept of the educating city is particularly functional to the Trans-Urban EU-China project, to the transition to socially integrated cities and to the pedagogical objectives that this transition suggests. The construction of a socially integrative city (inclusive, cohesive and livable) also depends on the efforts made to enhance the strengthening of the sense of community by means of a proactive education capable of developing a socio-cultural dimension and social capital, as highlighted in Chapter 2 of this book and underlined by Müller et al. (2019). The beating heart of the concept of the educating city refers indeed to the ability of the city to become an educating (and self-educating) "community" and a place of significant social relationships, aimed at harmonizing different people and behaviors and stimulating mutual recognition and respect, symbolic identification, expression and integration of cultures and social inclusion (see Bertolini 1989; Borello 1989; Borja 1998; Perucca 2007; as well as the publications edited by the International Association of Educating Cities-IAEC: Bauman 2008; del Pozo 2008; Lipovetsky 2017; Tarabini 2017). In short, thanks to the educating city/community, we can better understand the role of "education" and community educational networks in sustainable urban development, their influence in strengthening the social fabric and their importance in promoting social harmony and unity.

Given the above, an educating city is a city that is capable of involving its inhabitants in educationally relevant interactive dynamics and in a continuous learning and educational process, transversal to all ages of life (Fernando and Morell 1990; Bosch 2008). This involvement allows individuals to grow, expanding their opportunities for improvement and increasing their possibilities of achieving self-realization objectives. At the same time, it allows the city itself to develop its own evolutionary potential, taking advantage of the activated educational-relational paths and widespread accessibility to learning (Piazza 2013; Angori 2016). It is therefore a win-win situation, in which the positive implications for both parties not only relate to the demands for economic progress in general, but also to those for humanization, aiming at the full maturation of people. In this perspective, the educating city integrates school and university education, extending and enhancing its educational, cultural and informational offer; it harmonizes different educational and training actors and institutions of the territory; and it places 
a high value on the non-formal and informal dimension of "education" and learning. Furthermore, it makes a pedagogical reflection on its own spaces, with the objective of designing or making them available in order to satisfy the educational and relational needs of citizens (Frabboni 1990, 2006; Trilla Bernet 2005; Bosch 2008; Llop Torné 2009).

The aforementioned purposes were clearly highlighted at the time when the educating city became a prominent topic within the pedagogical landscape, referring, for example, both to the hypothesis of building an integrated educational system, aimed at making the city a great "educational laboratory" (Frabboni 1991, p. 35), and to a necessary alliance between pedagogy, urban planning and architecture (Gennari 1989), starting from the conscious need to assign educational meaning also to the "signs" that constitute the "urban texts" (Gennari 1995).

The current international notion of the educating city still embodies these purposes. However, the reference paradigm has changed over the last thirty years (from lifelong education to lifelong learning), in favor of a prevailing attention to economic outcomes of educational processes and of a substantially efficiency-based view of learning (Barros 2013). Furthermore, the terminology has also changed, to the extent that our original expression is now accompanied by the concept of the learning city (Longworth 2006). However, the number of contributions calling for the return to purely educational origins, for a dissociation of the learning city from such a limited perspective, and for the resurrection of an ethical and humanistic approach to learning (Osborne et al. 2013), which would continue to represent the city as a privileged place of encounter between educational concerns and democratic instances of human development (UNESCO 2014), is not negligible. In this respect, we cannot but think of Dewey (1940) and the relationship between education and democracy based on the concept of "community education"; and, even before Dewey, of the Greek "polis", where the "paideia" consisted basically in the rulers' capability to use education to form responsible individuals, able to provide for their own prosperity and to ensure the democratic prosperity of the community (Ortega Esteban 1990; Trilla Bernet 2005; Angori 2016).

The democratic yearning, therefore, has not vanished with the learning city, especially when the emphasis is placed on the beneficial effects of learning on the promotion of active citizenship, increasing participation in political and social life, personal and community well-being, social cohesion and the ability to react to sudden global changes (Longworth and Osborne 2010). In addition, it is particularly evident when the fulcrum of a learning city is identified in learning as an expression of a shared culture (Piazza 2015). Once again in line with Dewey (1916), the actualization of each person's potential (education as ex ducere), conceived as the ultimate meaning of democracy, is closely related to social efficiency determined by the possibility of cultivating values together through education, i.e., of structuring a shared culture from the bottom. However, if the literature on learning cities tries to rebalance 
the relationships at stake, the educating city has never lost its democratic input, remaining faithful to its genetic matrix, dating back to the 1970s: the paradigm of lifelong education (Meirieu 2008). Through the concepts of "educating community" or "cité educative" (UNESCO 1972), this paradigm does not revolve primarily around economic goals, but it rather aims to nourish people's critical and creative thinking, support the coexistence of differences and counter any form of alienation of the human potential through the total education of all and, for these reasons, it presents an explicit democratic dimension (Mencarelli 1964; Lengrand 1965, 1970; Lorenzetto 1976; Cropley 1979; Suchodolski 1992; Schwartz et al. 2009). This is why, in this paper, in order to mark a pedagogical distance from the functionalist drifts of the lifelong learning paradigm, we will continue to prefer and use the term educating city, embracing the genuinely educational and democratic spirit that animates the guiding idea of lifelong education.

With this, we do not want to state that the economic objectives must be excluded from the educating city, but that the community dimension (cum munus) should be the prevailing one: economic competition needs an educational perspective which places the participatory and relational sphere at the center, in order not to reduce the infinite potential of every human being to become an "economic agent", generating conflict between persons and peoples. Comparison and mutual understanding contribute, in fact, to the creation of richer personalities and a more integrated "social being", without mortifying everyone's differences and peculiarities.

Methodologically, the article adopts a critical-argumentative approach and examines two cases of educational museums (one in China and one in Europe), in which the typical ideal of the educating city has declined from two different perspectives: the first one being more linked to the participatory dimension of knowledge (Europe); the other one being more linked to the dissemination of knowledge as a strategic element of the "learning society" (China). These different instances can and must find an integration, as will be explored in the conclusions.

\section{The Educational Vocation of Museums in Europe: The Example of School and Education Museums}

We have seen how the prospect of an educating city intends to relaunch the city as a living space, with the expression of a community capable of experiencing itself as an active citizenship, which feeds its desire to know and communicate. If this is true, then it appears important to identify those poles of interest which allow expressing the educational potential of the city. In particular, we should enhance those institutions which, like museums, represent the collective memory of a community and can offer non-formal learning opportunities capable of reducing inequalities and reaching every social class in a welcoming and inclusive way (Gallina 2004). In this direction, museums can represent important places to foster 
proactive education policies, to preserve cultural heritage and to foster social capital, i.e., to find out some strategic factors for a socially integrative city (Müller et al. 2019). In recent years, museums have changed their role. For a long time, museums have been perceived and conceived as places of conservation for privileged people. This view began to change around the 1970s and 1980s thanks to the Nouvelle Muséologie movement. As it is well known, this movement, born in France and which soon spread throughout Europe and beyond, had the intention of eliminating the distance between museums and their users, investing museums with a key role in promoting the cultural and also economic development of a territory. In this way, museums became spaces for everyone without any kind of social or cultural distinction, places of cultural democratization and dynamic and interactive spaces capable of encouraging the emancipation of a community and the ability of its inhabitants to recognize themselves around a common heritage of knowledge and values as integral parts of their own collective identity (Maure 1996). This qualitative leap was theorized at the beginning of the seventies through the concept of the ecomuseum or community museum and gradually allowed shifting the attention of experts from the objects preserved in a museum to the experience that it allows to live (de Varine 2005; Beruglia et al. 2004). In this way, museums moved from the traditional passive function of preserving and displaying collections to that of presenting activities for visitors, capable of establishing new relationships between the user, the museum's heritage and their socio-cultural environment. Very interesting examples of this museological conception are the community museums of Mexico. These museums were instituted in the seventies and are considered living museums because their heritage is the result of a long process of dissemination, research and organization carried out by the members of the communities with the support of institutional advisors. Therefore, these community museums were conceived as a "meeting point» which «bring together the genuine concerns of the rural, urban, indigenous and racially-mixed communities of Mexico" (Yanes 2010, p. 25).

It cannot be denied that, in terms of results, there is still a lot to do to ensure that museums are conceived and perceived as places of everyone for everyone; however, we should recognize the Nouvelle Muséologie movement's merit of having opened a breach, capable of having people look at museums with "new eyes", including among their tasks also the educational one (Somoza Rodríguez 2013). Even today, there are "antiquated museums", which favor the conservative role and present themselves as temples reserved for a few selected people, but we must also observe the growth in the number of new-generation museums (recently founded or that have decided to change their vocation), which invest in education and aim to create increasingly dense and direct communication channels with the surrounding context (Hooper-Greenhill 2007). 
Among the new-generation museums with a distinctly educational vocation, we can certainly include school and education museums. The heritage preserved in these museums is very different from that contained in other types of more widespread and well-known museums, such as art museums, as it has no market or esthetic value, but its value is contained in the complexity and richness of the social relations it evokes, all referable to the variegated world of educational relationships. These are museums that often arise from a private initiative of a voluntary nature or that take shape within university departments through the involvement of small groups of professors of history of education. To a lesser extent, these museums are set up with public funds, as part of a cultural or educational institution (Somoza Rodríguez 2013, pp. 152-53).

In order to follow the first traces of these museums, we must go back to the 1970 s and 1980s, when the international movement of new educational museums spread to the countries of Northern and Central Europe, in the wake of Nouvelle Muséologie. The movement wanted to distance itself from the museum pedagogy of the nineteenth century, proposing a new type of museum, intended to enhance the historical educational heritage preserved in it (Carreño 2008).

When we speak of historical-educational heritage, we refer to a wide and varied typology of goods, which includes not only books and archival materials, but also material goods (e.g., school aids, school furniture elements, school buildings) and intangible goods (such as school-use costumes, values and practices). The lowest common denominator of these very different goods is the fact that they have been used and created for educational purposes (Meda 2013). Given their particular nature, school and education museums should be privileged places of interest for any city that aspires to be an educational city precisely because-if accompanied by adequate educational strategies - they allow users to evoke and relive an experience that unites many people regardless of age, gender and social status differences, i.e., a school.

In this regard, it may be useful to note that, even if we tend to speak about school and education museums as a single category, it should be specified that school museums retain assets preferentially linked to the school, while museums of education represent educational processes, which can also be carried out by other educational institutions. In addition, there are many different typologies of museums which aim to preserve and enhance the historical-educational heritage, such as childhood museums, museum schools, classroom museums, educational and/or scholastic museums and demo-ethno-anthropological museums, which often host reconstructions of ancient classrooms as evidence of one of the many facets of local culture.

Currently, school and education museums and related ones are well present in Europe; in fact, there are over 60 museums of this kind in Italy, 60 in Germany, 41 in France and 26 in Spain (Meda 2013, p. 512). At present, not all museums of historical-educational interest have proposed educational proposals. Many museums limit themselves to offering only conservation activities and guided tours conducted 
by a few volunteers. In addition, in many school and education museums, there are reconstructions of classrooms of different periods, one next to the other, each one with its typical school aids, in a kind of linear and peaceful representation of the educational processes, which are far away from the real modality of education in the past (Yanes 2010; Somoza Rodríguez 2013). Nonetheless, we all know that the resources that these museums can express at an educational level are almost unlimited precisely because the educational aspect is connoted in their genetic heritage. Therefore, these museums have all the characteristics to qualify as places of meeting and comparison, capable of raising questions about social identities and differences of the most recent and more distant educational pasts (Brunelli 2018).

There are many projects which show the educational potentialities of school and education museums as factors of a socially integrative city and spaces for exchange of knowledge and the collectivization of learning (Ascenzi and Patrizi 2014, pp. 687-89). For example, we can recall the experience promoted by CEINCE (Centro Internacional de la Cultura Escolar) in Berlanga de Duero in 2009, in collaboration with the team of an association of family members of Alzheimer's patients in Soria (psychologists, doctors, therapists, social workers), during which activities were carried out to stimulate the memory residues of a group of Alzheimer's patients through sounds, images and objects related to their scholastic past. The educational context was recreated in the museum spaces of CEINCE and was structured starting from the materials preserved in it. The results obtained were appreciable both for individuals, who showed sensitive signs of recovering memories of their past, and for all the people involved in this experience, who were able to share their school memories in an intense moment of socialization (Escolano 2010).

This is just one of the many paths of enhancement of the heritage preserved in the school and education museums, which shows the real "profit" that can be obtained from cultural heritage in general, a profit far more important than the economic one because it affects the well-being of a community, activating channels which allow reaching even the weakest people. This example also shows how the task of the various social actors that animate a city, in particular the institutional ones, is to create the conditions for promoting the well-being of citizens, solidarity coexistence and active participation, moving from the cultural capital available to the community. In this way, we can achieve the deepest sense of "civitas" as an aggregation of citizens who contribute to mutual growth through projects and actions, which enhance the potential of the city as an educating community, which allows every citizen (regardless of age and level of learning) to perceive themselves as a learner, i.e., as a person capable of generating new knowledge and appreciating its benefits (Gennari 1995). If a community manages to work in this direction, discovering day after day that learning is not an individual but a collective fact and that "learning to learn" is the real capital of a city and the keystone of an effective 
social integration, then we can confirm that the community has taken the main road of the educating city.

\section{Creating More Inclusive Learning Spaces in China: Science and Technology Museums in China}

Educational processes play an important role in socially integrative cities. Learning spaces such as museums can be treated as a part of the education function of educating cities. These were the focal points of the analysis conducted with respect to school and education museums in Europe. There is no research on these museums in China. However, there are other types of educational museums, i.e., science and technology museums, that can be considered as expressions of the philosophy of an educating city and, therefore, as tools for achieving social integration and inclusion.

The easier it is to access knowledge, the more you can participate in the inclusive society construction process, especially for the kids and people living in countries. In China, this kind of effort seems more important because of the serious regional development gap. Since the reform and opening in 1978, the eastern region benefited from policy preferences and market forces and entered a fast development tunnel. The share of the national GDP of the eastern region increased from $40 \%$ to $50 \%$ in two decades ( $\mathrm{Li}$ and Huang 2020, p. 78). In contrast, the percentage of the national GDP of the central, western and northeastern regions dwindled. Furthermore, the fiscal spending per capita of the eastern region was the highest during 2000-2018, where the eastern region boasted the highest per capita spending on many public services, particularly education, science and technology and community services, and this created a significant regional education gap in China.

This gap not only exists in the possibility to access education but also in the quality of education. According to the China Compulsory Education Quality Monitoring Report in 2018, rural students lag behind urban students in their scientific inquiry ability. Most teachers do not know an effective way to improve the inquiry ability of students, school Science and Technology Information (STI) labs cannot provide useful and dynamic knowledge for students and the usage rate of school STI labs is quite low.

Considering such a background, the creation of more inclusive learning spaces is an important part of the construction of educating cities in China. The Science and Technology Museum project offers several ways to help. The Science and Technology Museum project began in the late 20th century and it was taken as a large-scale education and science popularization infrastructure to provide an inclusive learning space for people in different areas. The first science and technology (S\&T) museum was established in Tianjin in 1995, and since then, numerous museums have sprung up in various Chinese provinces (Chen and Fang 2006). Most of these S\&T museums act as science centers and learning spaces where education has a key role. Nowadays, 
China has formed a modern S\&T museum system of its own which can provide S\&T resources and technical services to different regions and different groups of residents.

The modern S\&T museum system can be divided into three levels. The first level is the physical science and technology museum, which is the traditional form of museum. These museums display the history of science and technology, creating S\&T activities for the public to experience. In China, every province has its own S\&T museum, and some of the big cities have also constructed an S\&T museum and taken it as an important place for science education. At the end of 2014, there were 129 qualified S\&T museums distributed in different regions. One of the most important ones is the China Science and Technology Museum in Beijing, which is located in Chaoyang district, near the main Olympic stadium.

Although S\&T museums are becoming more and more accessible in China, they are still not enough for the huge number of inhabitants and considering the large regional scale. Another important S\&T museum was born with the special mission to bridge the gap between remote and rural areas. In March 2016, China's State Council General Office launched "The Civic Scientific Literacy Action Implementation Plan" (2016-2020). This document emphasizes the need to improve the scientific literacy of the Chinese population. The China Science and Technology Association (China Science and Technology Association 2017) supported the S\&T Museum project of rural middle schools, started in 2012, to reduce the science educational distance between cities and the countryside. Up to the present day, there has been an important development of S\&T museums in rural areas, so much so that at the end of 2016, there were almost 300 museums, 77 of which located in Tibet, which has at least one museum in each country.

A second level of the S\&T museum system in China is represented by mobile science and technology museums and science popularization caravans, which are popular and important in remote areas in China. The pilot project of China mobile science and technology museums was officially launched in 2011. In 2013, the project received support from the Ministry of Finance, with an annual financial input of CNY 80 million to encourage the establishment of new mobile science and technology museums. At present, mobile science and technology museum projects have covered 23 provinces and autonomous regions. By the end of 2017, China mobile science and technology museums had 364 sets of exhibitions and held 2339 itinerant exhibitions, which have benefited 87.5 million people (Long 2008). Science popularization caravans are another kind of mobile S\&T museum. The caravans allow circulating exhibitions of scientific content even in the most remote areas and to allow an ever-larger number of people (young people but also adults) to have a first approach with scientific knowledge. This caravan project started in 2000. By the end of 2014, a total of 865 science popularization caravans had been distributed nationwide, with 129,900 activities and 1611.3 million 
visitors (China Science and Technology Association 2017). Currently, each municipality, province and autonomous region has its own scientific popularization caravan.

The third level of the S\&T museum system in China is represented by virtual S\&T museums, which are very popular in this new era of the Digital Revolution. Most S\&T museums provide online services and are open to all citizens. In December 2005, the Digital Science and Technology Museum began to construct the only basic science infrastructure platform projects which had public access. The project aims to use modern information technology to transform the results of scientific research, science education and popular science activities into digital S\&T educational resources and use various information technologies to integrate high-quality digital science resources for the whole society and build an online platform for searching and sharing information. The online S\&T museums provide convenient and fast public science services for young people all over the world. Furthermore, the online S\&T museums were very useful in providing remote learning opportunities for students during the quarantine in 2020 when COVID-19 overspread in China.

The primary purpose of the S\&T museums is to support the dissemination of scientific knowledge among increasingly broader sections of the population. The importance and role of education are becoming more and more essential. However, due to the lack of professional staff in the S\&T museums and the limited financial support, the S\&T museums in China are far from perfect, especially the operation of the mobile S\&T museums and the virtual S\&T museums. Lately, the bottom-up online science education practices have lit up a new path for STEM learning. Many organizations and STI companies are leading this kind of movement. For example, Ping An China and the China Next Generation Education Foundation launched the "AI Not Reading Alone-Youth Science and Technology Literacy Improvement Program" in 2019. This project provides science classes for 1000 remote rural primary schools across the country. The most important part is that this project invited experts and scholars to develop suitable teaching materials and experimental contents for rural children, assisting rural schools in the construction of popular science laboratories and providing relevant training for principals and teachers.

Investing in the future is a main topic for China, in order to explore the educational function of S\&T museums as an expression of an authentic educating city and to improve human capital, especially the scientific literacy of the whole country, which require continuous efforts from the whole society. Although the practices in China are still to be perfected, they represent fundamental action which must be improved to pursue the path of social integration and growth both in large and small communities. The various educational initiatives promoted in China through science and technology museums represent one of the possible expressions of the educating city which-in this case- through institutions is mobilized to enrich citizens culturally, thus helping to support the growth of both individuals and the collectivity. 


\section{Conclusion: The Educating City to Face the Challenges of Globalization}

The main purpose of this article is to show how the integration of economic competition into a participatory and relational sphere is necessary to foster an effective socially integrative city by strengthening the role of museums in particular. The theoretical and applicative analysis explained in the previous paragraphs suggests that the educating city can be seen at the crossroad between two forms of globalization: (a) the first one, which puts the individuals' and the community's self-fulfillment into the foreground in the name of cooperation and solidarity; (b) the other one, focused on economic competition. Therefore, the first form of development enhances the differences and peculiarities among people and cultures, while the second form of development pushes towards a lifestyle's homologation, as every aspect of life is brought back to the economic dimension.

Anyway, it is even too easy to interpret the polarity just described in a Manichean way. In fact, people live both within the material production systems and within the cultural and symbolic systems. These two spheres can (and must) know an integration. The economic push towards globalization can be a spur to integration among peoples, as it enables peoples to confront and relate to each other, thus counterbalancing the temptation of each culture to claim its idiosyncratic exclusivity opposing the "Other", leading to fragmentation. If, however, the dynamics of power connected to economic competition prevail, then the self-determination of peoples and cultures weakens. Democracy consequently enters a "crisis" (cfr. Crozier et al. 1975) and becomes hostage to powers that prevent its effective deployment. In this case-as Crouch (2004) observes-a passive attitude of people towards democracy prevails: many individuals of Western societies claim, in fact, their "rights" (to private property, to be protected, to criticize the politicians' work and also that of getting angry with political failures: corruption, lack of results, growing inequality, etc.), forgetting, however, the importance of active commitment in co-building democracy (by participating in politics through voting, associating and organizing, trying to be better informed, proposing alternatives, etc.).

The competitive aspects - related to the "power of knowledge"-and the cooperative aspects-related to the co-construction of knowledge in a cooperative perspective-are not, therefore, to be seen as opposed: they are co-present moments, and they have to be integrated. The epistemology of complexity underlines that a complex system is capable of developing "emerging properties" (or "collective properties"), precisely thanks to the competition-cooperation that is triggered between the various parts which compose a system (Anderson 1972; Waldrop 1992). These "parts" are often "agents" themselves, as happens in social and economic systems, that is, endowed with self-organization and proactivity but also with an "openness" to the environment (von Bertalanffy 1968).

The museum's role in the analysis carried out highlights the complementary needs just mentioned: in the first analysis, the museum is described as a "collective 
fact", in which "learning" is subordinated to social integration and social construction processes; in the other case, the opposite is true, that is to say integration is a by-product of knowledge, since "knowledge is power" and without this power, the minimum requirements for participation are missing.

A city is typically an "open system" because it exists in continuous interrelation with the environment. Prigogine notes that a city is not a crystal preserved in a bell jar because a city is inconceivable beyond its interrelationships with the rest of the world. Therefore, an educating city has a "double face": on the one side, it has "its own personality" (IAEC 2004); on the other side, it is characterized by a "bottom-up" participatory process, as highlighted by the epistemology of complexity. An educating city represents a "lived place" (Magnaghi 2011; Dardel [1952] 1990) able to counterbalance a globalization conceived exclusively on the side of economic efficiency that empties places of its intrinsic quality. In this sense, museums-as the case studies of educational museums demonstrate - can represent urban laboratories, capable of encouraging processes of participation, comparison and cultural exchange.

However, the educating city as an "open city" which has continuous interactions with the environment must be able to actively react also to constraints and pressures of different types, including the competitive ones, putting in place a "critical adaptation" (IAEC 2004): "persons must educate themselves for the sake of their critical adaptation to and active participation in the challenges and possibilities opening up as a result of the globalization of all economic and social processes, so that they can intervene-through their local world-in a complex international scenario, and in order to remain autonomous subjects in the face of a flood of information controlled by economic and political power centres" (ibid.).

The challenges of globalization, therefore, are not taken up in an uncritical or passive way, but by asserting the cities' "voice". The role of the educating city is therefore that of promoting the development of a civic and cultural awareness thanks to self-organizational processes, while maintaining an "openness" to the context: undergoing pressure but also, thanks to its own "agency", advancing context requests and proposals that can put pressure on politics and the economy. In this sense, it would be appropriate that opinion groups, cooperation networks, neighborhood welfare and voluntary activities do not remain forms of self-help which "involve turning away from politics, [and] they cannot be cited as indicators of the health of democracy, which is by definition political" (Crouch 2004, p. 16). They have to assume the form of the political proposal. For example, with regard to the Italian context, the role of mayors and local administrators is considered by people still capable of affecting reality. The educating city carries out a political activity, by integrating the cultural and educational dimension with the civic-institutional dimension and the economic one too. It is a laboratory of neo-democracy, as it can develop new forms of active participation and self-determination. Having 
a personality is "formative" towards inhabitants; on the other hand, it can allow a city to become an incubator of proposals, lifestyles, instances and projects that can put pressure on the outside world and also on politics.

Confirming that the participatory and the competitive aspects are complementary and answer the different needs of the contexts in which they are developed, it should be emphasized, finally, that the concepts of "integration" and "participation" have different nuances: "participation" requires the active contribution of the person and the community, while "integration" can be governed from above in a "top-down" way.

Author Contributions: Introduction, F.d.; paragraph 2, E.P.; paragraph 3, Z.X.; Conclusion, S.P. All authors have read and agreed to the published version of the manuscript.

Funding: This research was funded by the TRANS-URBAN-EU-CHINA project.

Conflicts of Interest: The authors declare no conflict of interest.

\section{References}

Anderson, Philip W. 1972. More is different. Science 177: 393-96. [CrossRef] [PubMed] Angori, Sergio. 2016. Learning city. Accademia Etrusca di Cortona XXXV: 57-66.

Ascenzi, Anna, and Elisabetta Patrizi. 2014. I Musei della scuola e dell'educazione e il patrimonio storico-educativo. Una discussione a partire dall'esperienza del Museo della scuola «Paolo e Ornella Ricca» dell'Università degli Studi di Macerata. History of Education E Children's Literature 9: 685-714.

Barros, Rosanna. 2013. From lifelong education to lifelong learning. European Journal for Research on the Education and Learning of Adults 1: 33-47.

Bauman, Zygmunt. 2008. Public Space. In Education and Urban Life: 20 Years of Educating Cities. Edited by Eulàlia Bosch. Barcelona: International Association of Educating Cities, pp. 47-56. Available online: https://www.edcities.org/en/wp-content/uploads/sites/2/ 2015/02/Education-and-Urban-Life.pdf (accessed on 8 July 2020).

Bertolini, Piero. 1989. La città: Un oggetto pedagogico? In La Città Educante. Edited by Mario Gennari. Genova: Sagep, pp. 45-59.

Beruglia, Cristoforo Sergio, Andrea Stanghellini, and Silvia Infusin. 2004. Il Museo Educativo. Milano: FrancoAngeli.

Borello, Claudio. 1989. La città come utopia educativa. In La città educante. Edited by Mario Gennari. Genova: Sagep, pp. 61-83.

Borja, Jordi. 1998. Ciudadanía y espacio público. In Ciutat Real, Ciutat Ideal. Significat i funció a l'espai urbà Modern. Edited by Pep Subiròs. Barcelona: CCCB.

Bosch, Eulàlia, ed. 2008. Education and Urban Life: 20 Years of Educating Cities. Barcelona: International Association of Educating Cities, Available online: https://www.edcities. org/en/wp-content/uploads/sites/2/2015/02/Education-and-Urban-Life.pdf (accessed on 8 July 2020). 
Brunelli, Marta. 2018. L'educazione al patrimonio storico-educativo. Approcci teorici, modelli e strumenti per la progettazione Didattica e formative in un museo della scuola. Milano: FrancoAngeli.

Carreño, M. 2008. Los nuevos museos de educación, un movimiento intenacional. Encounters on Education / Encuentros sobre Educación 9: 75-91.

Chen, Simin, and Jiazeng Fang. 2006. A comparison of Science and Technology Museum between China and UK. Science Popularization 2: 36-42.

Cropley, Arthur John, ed. 1979. Lifelong Education: A Stocktaking. Hambourg: UIE.

Crouch, Colin. 2004. Post-Democracy. Cambridge: Polity Press.

Crozier, Michel, Samuel P. Huntington, and Joji Watanuki. 1975. The Crisis of Democracy. Report on the Governability of Democracies to the Trilateral Commission. New York: New York University Press.

China Science and Technology Association. 2017. Research report on the construction and development of modern science and technology museum system with Chinese characteristics.

Dardel, Éric. 1990. Homme et la terre. Nature de la réalité géographique. Paris: CTHS. First published 1952.

del Pozo, Joan Manuel. 2008. The Concept of the Educating City Today. In Education and Urban Life: 20 Years of Educating Cities. Edited by Eulàlia Bosch. Barcelona: International Association of Educating Cities, pp. 23-32. Available online: https://www.edcities.org/ en/wp-content/uploads/sites/2/2015/02/Education-and-Urban-Life.pdf (accessed on 8 July 2020).

de Varine, H. L'ecomuseo. 2005. Le radici del futuro. Il patrimonio culturale al servizio dello sviluppo locale. Edited by D. Jalla. Bologna: Clueb, pp. 241-273.

Dewey, John. 1916. Democracy and Education. New York: The Macmillan Company.

Dewey, John. 1940. Education Today. New York: G.P. Putnams Sons.

Escolano, Benito Augustín. 2010. Sherlock Holmes goes to school. Ethnohistory of the school and educational heritage. History of Education E Children's Literature 5: 29-32.

Fernando, Jordi, and Sussi Morell, eds. 1990. La Ciudad Educadora. Barcelona: Ayuntamiento de Barcelona.

Frabboni, Franco. 1990. La integración escuela-territorio. In La Ciudad Educadora. Edited by Jordi Fernando and Sussi Morell. Barcelona: Ayuntamiento de Barcelona, pp. 153-62.

Frabboni, Franco. 1991. Un'aula grande come la mia città. In La città educative. Edited by Franco Frabboni and Luigi Guerra. Bologna: Cappelli, pp. 34-46.

Frabboni, Franco. 2006. Una politica grande per i più piccoli. In La città educativa e i bambini. Edited by Franco Frabboni and Flavio Montanari. Milano: FrancoAngeli, pp. 11-31.

Gallina, Vittoria. 2004. Opportunità di apprendimento in età adulta: La fruizione dei beni culturali. In Musei e pubblico. Un rapporto educativo. Edited by Emma Nardi. Milano: FrancoAngeli, pp. 129-44.

Gennari, Mario, ed. 1989. Architetture della città educante. In La città educante. Genova: Sagep, pp. 135-58.

Gennari, Mario. 1995. Semantica della città e educazione. Venezia: Marsilio. 
Hooper-Greenhill, Eileau. 2007. Museums and Education: Purpose, Pedagogy, Performance (Museum Meanings). New York: Routledge.

IAEC. 2004. Charter of Educating Cities; Barcelona: IAEC. Available online: http://www. edcities.org/en/charter-of-educating-cities/ (accessed on 23 July 2020).

Lengrand, Paul. 1965. L'éducation permanente. Paris: Peuple et Culture.

Lengrand, Paul. 1970. An Introduction to Lifelong Education. Paris: UNESCO.

$\mathrm{Li}$, Xihui, and Jixin Huang. 2020. Building a moderately prosperous society in all respects-regional coordination. China Economist 15: 73-107.

Lipovetsky, Gilles. 2017. Educating Cities and Creative Cities: Paths to Better Coexistence. In City, Living Together and Education. Edited by Aina Tarabini. Barcelona: International Association of Educating Cities, pp. 14-19. Available online: https://www.edcities.org/en/wp-content/ uploads/sites/2/2017/07/Monograph-City-Living-Together-and-Education.pdf (accessed on 8 July 2020).

Llop Torné, Josep Maria. 2009. City, Urban Planning and Education. Barcelona: AICE, Available online: https://www.edcities.org/en/wp-content/uploads/sites/2/2009/10/Monogr\% C3\%A1fico-2009_en.pdf (accessed on 8 July 2020).

Long, Jinjing. 2008. Review on the project development of China mobile science and technology museum. Science and Technology Association Forum 7: 19-21.

Longworth, Norman. 2006. Learning Cities, Learning Regions, Learning Communities. London: Routledge.

Longworth, Norman, and Michael Osborne, eds. 2010. Perspectives on Learning Cities and Regions. Leicester: Niace.

Lorenzetto, Anna. 1976. Lineamenti storici e teorici dell'educazione permanente. Roma: Studium.

Magnaghi, Alberto. 2011. Draft of the Territorialists' Society Manifesto. Available online: http:/ /www.societadeiterritorialisti.it/wp-content/uploads/2013/05/110221b_ draft.of.the.territorialists.society.manifesto.pdf (accessed on 23 July 2020).

Maure, Marc. 1996. La nouvelle muséologie, qu'est-ce que c'est? In Museum and Community. II Icoform study Series 25; Edited by Martin R. Schärer. pp. 127-32.

Meda, Juri. 2013. La conservazione del patrimonio storico-educativo: Il caso italiano. In La historia de la cultura escolar en Italia y en España: Balance y perspectivas. Edited by Juri Meda and Ana Badanelli. Macerata: Eum.

Meirieu, Philippe. 2008. Lifelong Education: A Political Option. In Education and Urban Life: 20 Years of Educating Cities. Edited by Eulàlia Bosch. Barcelona: International Association of Educating Cities, pp. 228-38. Available online: https://www.edcities.org/en/wp-content/ uploads/sites/2/2015/02/Education-and-Urban-Life.pdf (accessed on 8 July 2020).

Mencarelli, Mario. 1964. Educazione permanente. Dall'educazione di base all'educazione dell'adulto. Brescia: La Scuola.

Müller, Bernard, Paulina Schiappacasse, Jianming Cai, and Enpu Ma. 2019. D 6.6 Workshop Report on "Theoretical aspects of transition towards urban sustainability and the role of socially integrative cities". In Transition towards Sustainability through Socially Integrative Cities in the EU and in China. Edited by IÖR and Trans-Urban-EU-China. Dresden: IÖR, Technische Universität Dresden, Chinese Academy of Sciences. 
Ortega Esteban, José. 1990. La idea de ciudad educadora a través de la historia. In La Ciudad Educadora. Edited by Jordi Fernando and Sussi Morell. Barcelona: Ayuntamiento de Barcelona, pp. 91-102.

Osborne, Michael, Peter Kearns, and Jin Yang. 2013. Learning cities. International Review of Education 4: 409-23. [CrossRef]

Perucca, Angela. 2007. Il gioco del convivere nella città globale. In L'accoglienza del Bambino nella città Globale. Edited by Pierpaolo Limone. Roma: Armando, pp. 39-50.

Piazza, Roberta. 2013. Learning City. Aspirazioni e ideali per le città del benessere. Roma: Aracne.

Piazza, Roberta. 2015. Le learning city. In La città che apprende. Edited by Edaforum. Scandicci: La fabbrica dei saperi.

Schwartz, Bertrand, Guy Jobert, and Henri Desroche. 2009. L'éducation permanente, un projet d'avenir. Education Permanente 180. Available online: http:/ /www.education-permanente. fr/public/articles/articles.php?id_revue=1698\&id_article=1912\#resume1912 (accessed on 8 July 2020).

Somoza Rodríguez, Miguel. 2013. Museología de la educación: ¿Divulgación cultural, atractivo turístico o práctica historiográfica? In La Historia de la cultura escolar en Italia y en Espana: Balance y Perspectivas. Edited by Juri Meda and Ana Maria Badanelli. Macerata: Eum, pp. 141-66.

Suchodolski, Bogdan. 1992. Educazione Permanente in profondità. Padova: Alfasessanta.

Tarabini, Aina, ed. 2017. City, Living Togheter and Education. Barcelona: IAEC, Available online: https://www.edcities.org/en/wp-content/uploads/sites/2/2017/07/MonographCity-Living-Together-and-Education.pdf (accessed on 8 July 2020).

Trilla Bernet, Jaume. 2005. La idea de ciudad educadora y escuela. Revista Educación Y Ciudad 7: 73-106.

UNESCO. 1972. Learning to Be. Paris: Unesco.

UNESCO. 2014. Beijing Declaration on Building Learning Cities; Beijing: Unesco. Available online: https:/ / unesdoc.unesco.org/ark:/48223/pf0000226755 (accessed on 25 September 2020).

von Bertalanffy, Ludwing. 1968. General System Theory: Foundations, Development, Applications. New York: George Braziller.

Waldrop, Morris Mitchell. 1992. Complexity. The Emerging Science at the Edge of Order and Chaos. New York: Simon Schuster.

Yanes, Cristina. 2010. The museum as a representation space of popular culture and educational memory. History of Education E Chidren's Literature 6: 19-31.

(C) 2021 by the authors. Licensee MDPI, Basel, Switzerland. This article is an open access article distributed under the terms and conditions of the Creative Commons Attribution (CC BY) license (http://creativecommons.org/licenses/by/4.0/). 